Inter-American Development Bank

Institutional Capacity and Finance Sector

TECHNICAL NOTES

No. IDB-TN-166

The Role of Foreign

Technology and

Indigenous Innovation in Emerging Economies:

Technological Change and Catching Up

Xiaolan Fu

Carlo Pietrobelli

Luc Soete 


\title{
The Role of Foreign Technology and Indigenous Innovation in Emerging Economies: Technological Change and Catching Up
}

\author{
Xiaolan Fu \\ Carlo Pietrobelli \\ Luc Soete
}

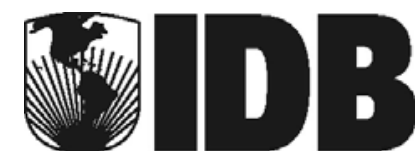

Inter-American Development Bank 2010 
(C) Inter-American Development Bank, 2010

www.iadb.org

The Inter-American Development Bank Technical Notes encompass a wide range of best practices, project evaluations, lessons learned, case studies, methodological notes, and other documents of a technical nature. The information and opinions presented in these publications are entirely those of the author(s), and no endorsement by the Inter-American Development Bank, its Board of Executive Directors, or the countries they represent is expressed or implied.

This paper may be freely reproduced provided credit is given to the Inter-American Development Bank.

1300 New York Ave. NW, Washington, D.C., U.S.A.

Contact: Carlo Pietrobelli (carlop@iadb.org) 


\begin{abstract}
This article explores in depth the role of indigenous and foreign innovation efforts in technological change and catching up in emerging economies. It also looks at the interaction between indigenous and foreign innovation. The article presents original evidence and argues that, despite the potential offered by globalisation and a liberal trade regime, the benefits of international technology diffusion can only be delivered with parallel indigenous innovation efforts and the presence of modern institutional and governance structures and conducive innovation systems. This conclusion is compounded by the expected inappropriateness of Northern technology for countries in the developing South, which calls for greater efforts to develop indigenous innovation. In this sense, indigenous and foreign innovation efforts are complementary.
\end{abstract}

JEL Codes: F23, O33.

Key words: indigenous innovation, technology transfer, technological capabilities, technological change, emerging economies.

\footnotetext{
* The authors thank participants at the Sanjaya Lall Programme for Technology and Management for Development (SLPTMD) Oxford Conference (May 2008) and an anonymous referee for helpful and constructive comments, and UNIDO for financial support. The authors are also Director (Fu) and Senior Research Associates (Pietrobelli and Soete) of the SLPTMD, University of Oxford, UK. The opinions expressed in the paper are those of the authors and do not necessarily reflect those of their respective organizations.
} 


\section{Introduction}

It is widely recognised that differences in productivity are a major source of cross-country income variations and that technological change drives productivity growth. Technological innovation is therefore a key element of industrialisation and catch-up in developing countries. One of the controversies is whether the sources of technological change are indigenous or based on foreign innovation efforts or a combination of the two, and if so, which combination.

On one hand, innovation is costly, risky and path-dependent. Hence it is more efficient for developing countries to simply acquire foreign technology created in developed countries. In principle, if innovations were easy to diffuse and adopt regardless of their nature and type, a technologically backward country could catch up rapidly by absorbing the most advanced technologies (Romer, 1994; Grossman and Helpman, 1994; Eaton and Kortum, 1995). With the expectation to "trade market for technology," many developing countries "raced to the bottom" to attract foreign direct investment (FDI) using various financial and fiscal incentive schemes.

On the other hand, there is the view that technology diffusion and adoption is neither costless nor unconditional. It relies on substantial and well-directed technological efforts (Lall, 2001 and 2005) and on absorptive capacity (Cohen and Levinthal, 1989). Further, technical change is often biased and foreign technologies developed in industrialised countries may not be appropriate for the economic and social conditions of developing countries (Atkinson and Stiglitz, 1969; Basu and Weil, 1998; Acemoglu, 2002). In addition, it cannot be simplistically assumed that the private interests of multinational enterprises (MNEs) coincide with the social interests of the host countries (Lall and Urata, 2003). The available empirical evidence on the effects of indigenous or foreign innovation is mixed. Studies largely fail to provide convincing evidence that there is a significant positive technological transfer or spillover effect of FDI on local firms. ${ }^{1}$

Within this broad and ongoing debate, the role of indigenous innovation and its diffusion/spillover effect in the catching-up process has not received the attention it deserves. Many relevant questions remain unanswered. What drives technological change and catching up in developing countries, particularly in middle-income countries? To what extent can developing countries successfully build their own modern industries through technology acquisition via imports and FDI? What are the roles of indigenous innovation and its diffusion? What is the relationship between indigenous innovation and the acquisition of foreign technology in an increasingly globalised world, and how does this interaction change

\footnotetext{
${ }^{1}$ For surveys of the literature on spillovers from FDI see Görg and Strobl (2001), Blomström and Kokko (1998) and Meyer (2004).
} 
to respond to the specific characteristics of a country? How does integration in global value chains enable a developing country to access and learn from foreign technology? This addresses these questions based on a series of new empirical studies on technology acquisition through FDI and indigenous innovation in emerging economies. ${ }^{2}$

Impressively rapid economic growth in Brazil, India, and China in the past three decades is changing the landscape of the world economy. ${ }^{3}$ These countries are quickly catching up with the leading industrial countries, and this process is becoming a remarkable economic force that is influencing the world economy. These three countries account for about 40 percent of the total world population and 13 percent of total world income (in 2007), and most importantly, these countries' incomes are rising at a speed similar to those of Japan and Korea when their economies were taking off (World Bank, 2007). The emergence of Brazil, India, and China has important implications for the world, not only in terms of economic impact, but also in terms of their experiences in guiding and promoting the growth process. These countries have opened up to international trade and investment, though to different degrees and with different speed and strategies, while at the same time they have put increasing emphasis on indigenous knowledge creation and innovation, though again to different extents and with varying success. Experiences from these emerging economies may provide valuable lessons for other developing countries with regards to industrial, technology, and trade policies.

The remainder of this article proceeds as follows. Section II examines some stylised facts about these emerging economies. Section III analyzes the possible benefits from international technology transfer and the transmission channels. Section IV discusses the importance of the appropriateness of technology for catch-up and the capacity of developing countries to create new technology. Section V discusses the interactions between foreign technology transfer and indigenous innovation. Section VI concludes with an evaluation of the evidence and discusses policy implications for other developing countries struggling to upgrade technology and catch up to the developed world.

\section{Technology and Economic Take-off in Emerging Economies}

The rise of Brazil, India, and China is changing the landscape of the world economy. For instance, China's average annual GDP growth rate in the past 30 years is 9.8 percent, more than three times the average 3.0 percent annual growth rate of the world economy during the same period. In 2007, the annual GDP growth rate was 13.0 percent in China, 9.1 percent in India, and 5.4 percent in Brazil - all substantially higher than the world average growth rate

\footnotetext{
${ }^{2}$ These studies are forthcoming in a Special Section of World Development edited by the authors of the present paper.

${ }^{3}$ South Africa and Russia are often included in this group. However, in this paper we focus on the two largest Asian countries and on Brazil, on which new evidence has become available.
} 
in that year of 3.8 percent. In 2008, in spite of the worldwide economic crisis, these economies continued to grow much faster that the world's 1.7 percent average at 9.0 percent in China, 6.1 percent in India, and 5.1 percent in Brazil. ${ }^{4}$ By 2007, China was ranked among the four largest economies in the world in terms of total GDP. The pace and duration of economic growth of these economies resembles Korea and Japan's performance during the three decades after 1960 (Figure 1). The combination of this fast growth and the large size of these economies makes them a significant economic development experience with a global impact (Freeman, 2005).

Figure 1. Growth Rates of Brazil, India, and China Compared with Japan's and Korea's Take-off Years

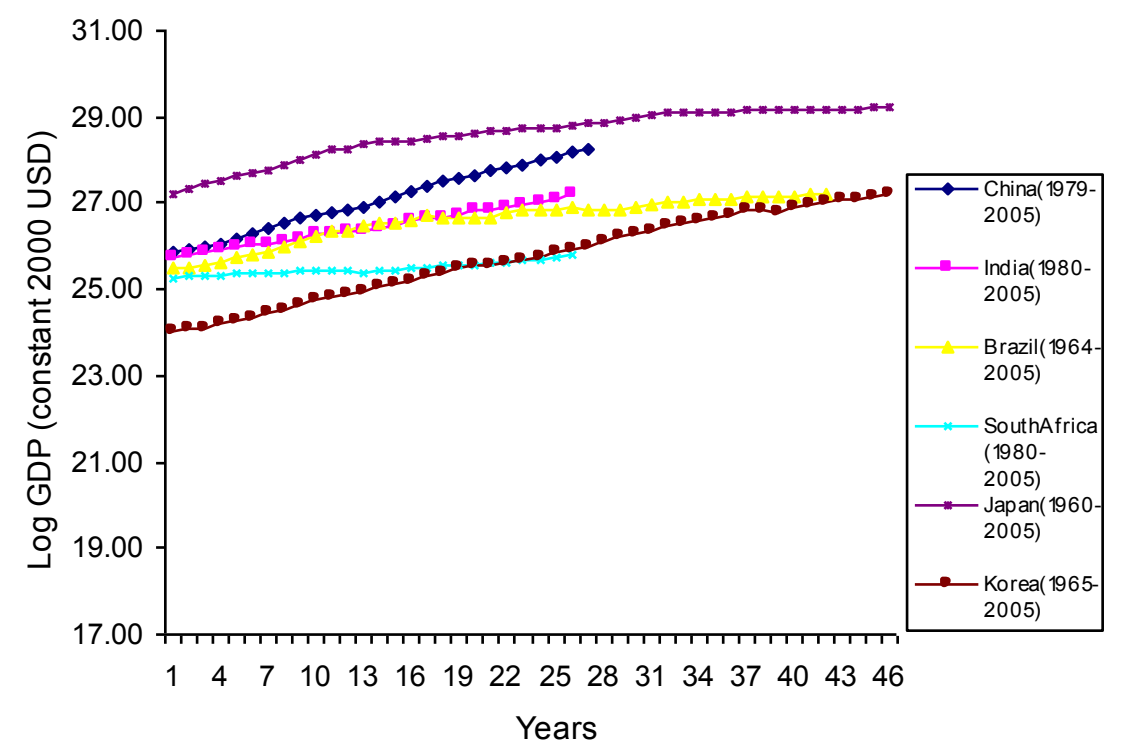

Source: World Bank (2007)

Technological capabilities in these emerging economies (Lall, 1992) - a central driver of technological upgrading - have also grown significantly, and in some industries they are catching up with the industrialised countries. Since 2000, China and India have experienced a rapid surge in patent applications. The number of patents that belong to socalled Triadic Patent Families ${ }^{5}$ where the application was made by Chinese researchers increased more than seven times from 2000 to 2007. For India, the number increased about three times (Figure 2). China's export market share of products that are intensively based on research and development (R\&D) increased to 13 percent from 3 percent from 2000 to 2008, moving close to the 15 percent and 19 percent market shares held by the United States and the European Union (15 countries), respectively. This illustrates the rapid structural change and industry upgrading that is currently taking place in China (Table 1).

\footnotetext{
${ }^{4}$ In 2009, China's GDP grew at 8.7 percent, and India's at 5.7 percent.

${ }^{5}$ These are patents applied for/granted in the United States, Europe and Japan.
} 
Figure 2. Granted Patents Belonging to Triadic Patent Families

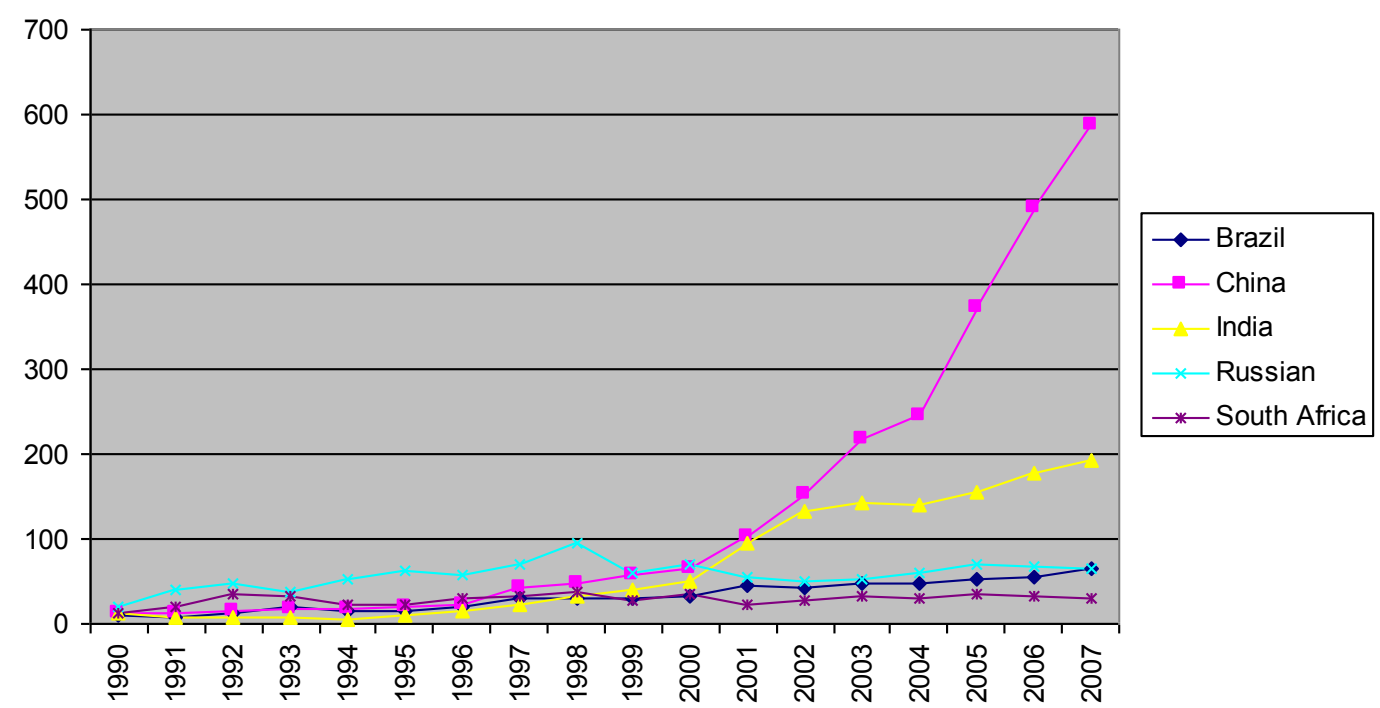

Source: OECD, STAN STructural ANalysis Database, 2010

Table 1. Export Market Share (percent): R\&D-Intensive Industries

\begin{tabular}{lrrrr}
\hline & $\mathbf{1 9 9 5}$ & $\mathbf{2 0 0 0}$ & $\mathbf{2 0 0 5}$ & $\mathbf{2 0 0 8}$ \\
\hline Japan & 14.51 & 8.12 & 5.55 & 4.73 \\
Korea & 3.22 & 2.68 & 3.05 & 3.41 \\
Mexico & 1.56 & 2.02 & 1.74 & 1.92 \\
United States & 23.47 & 20.37 & 15.89 & 15.41 \\
EU15 & 22.92 & 18.80 & 18.96 & 18.76 \\
China & & 2.97 & 9.21 & 13.09 \\
Russia & & 0.20 & 0.22 & 0.17 \\
South Africa & & 0.10 & 0.12 & 0.10 \\
\hline
\end{tabular}

Note: Five R\&D-intensive industries are: aerospace, electronics, instruments, office machines, and pharmaceutical. The figure is a simple average of the share of the five industries.

Source: OECD, STAN STructural ANalysis Database, 2010

Of course, despite sharing common features such as their large size, these emerging countries are very diverse in their factor endowments, economic structure, development history and strategy. All of these countries have opened up to international trade and investment. While Brazil mostly relied on its large domestic market (trade/GDP ratio was 27 percent in 2007), India relied much more on the international economy, with a trade/GDP ratio of 46 percent in 2007, and China experienced a dramatic export-led growth path with a trade/GDP ratio as high as 76 percent in 2007 . These countries also significantly reduced 
tariff barriers and opened up to imports of foreign goods. Over the 1990 to 2006 period, the average weighted tariff rate was reduced to 7 percent from 27 percent in Brazil, to 5 percent from 41 percent in China, and to 14 percent from 83 percent in India. They also opened up to international direct investment, with China and Brazil enjoying average FDI/GDP ratios of 3.2 and 3.4 percent, respectively, over the period 2000 to 2005 . While the figure in India was lower than that in China and Brazil, at 0.9 percent, it has been increasing rapidly since 1991. These countries have also spent significant and rising shares of GDP on royalty and licensing fees for foreign technology acquisition: between 0.8 percent (India) and 2.6 percent (China). They have sent many students abroad for education and introduced various policies to attract overseas diasporas to return to their countries (Table 2).

On the other hand, China, India, and Brazil are putting great effort into building indigenous technological capabilities. These three countries, together with the United States and the Russian Federation, stand as the top five countries in the world in terms of number of university enrolments in 2007 (Dahlman, 2010). Their expenditure on R\&D has also increased exponentially. In 2006, total R\&D expenditure in China was greater than that of Germany, the United Kingdom, and France, and was about a third of that in the European Union. In terms of its gross R\&D expenditure to GDP ratio, China is now moving close to the EU average (Figure 3).

Figure 3. R\&D efforts in selected countries, 2006

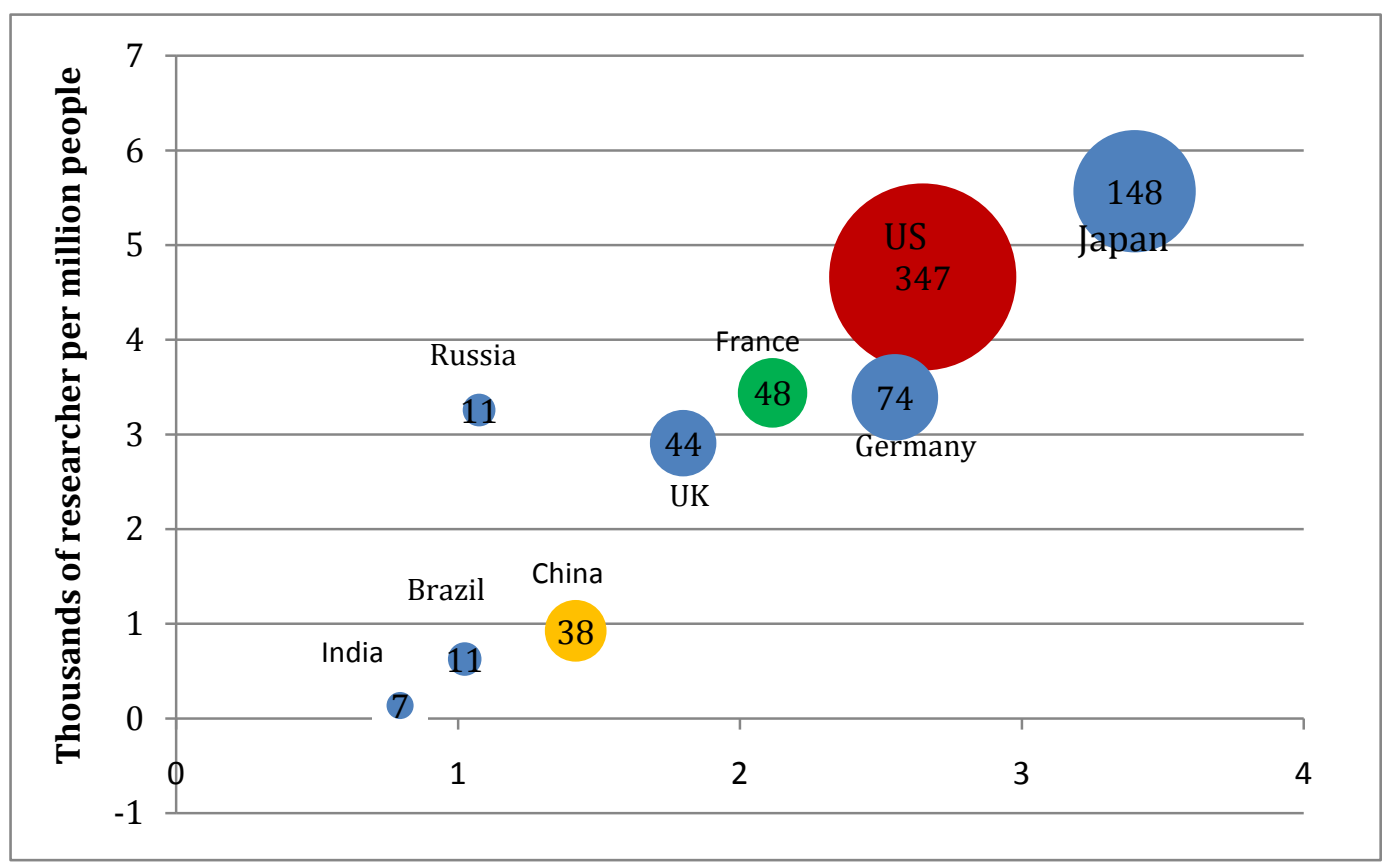

Spending on R\&D as \% of GDP

Source: World Bank (2010)

Note: Area of the bubbles shows the size of Gross $R \& D$ expenditure. 
Table 2. Acquisition of Foreign Knowledge: Brazil, China, and India

\begin{tabular}{|c|c|c|c|}
\hline & Brazil & China & India \\
\hline \multicolumn{4}{|l|}{ Trade (percent of GDP) } \\
\hline 1980 & 22 & 21 & 15 \\
\hline 2007 & 27 & 76 & 46 \\
\hline \multicolumn{4}{|l|}{ Merchandise imports (percent of GDP) } \\
\hline 1980 & 9.8 & - & 7.5 \\
\hline 2007 & 9.6 & 29.8 & 18.4 \\
\hline \multicolumn{4}{|c|}{ Manufactured imports (percent of merchandise imports) } \\
\hline 1980 & 41 & - & 39 \\
\hline 2007 & 64 & 68 & 46 \\
\hline \multicolumn{4}{|l|}{ Average tariffs (percent) } \\
\hline \multicolumn{4}{|l|}{$1990-1992$} \\
\hline Average simple tariff & 25.1 & 42.9 & 81.8 \\
\hline Average weighted tariff & 26.7 & 40.6 & 83.0 \\
\hline \multicolumn{4}{|l|}{2006} \\
\hline Average simple tariff & 12.3 & 8.9 & 17.0 \\
\hline Average weighted tariff & 6.8 & 5.1 & 13.8 \\
\hline \multicolumn{4}{|l|}{ Average Gross FDI/GDP } \\
\hline $2000-2005$ & 3.4 & 3.2 & 0.9 \\
\hline \multicolumn{4}{|l|}{ Royalty and license fee payments (US\$ million) } \\
\hline 1990 & 54 & 0 & 72 \\
\hline 2007 & 2,259 & 8,192 & 949 \\
\hline Percent of GDP & 1.72 & 2.56 & 0.80 \\
\hline Tertiary Students Studying Abroad 2007 & 21,556 & 421,128 & 153,312 \\
\hline As percentage of students studying abroad & 0.77 & 15.03 & 5.47 \\
\hline As percentage of tertiary students in the country & 0.4 & 1.9 & 1.1 \\
\hline
\end{tabular}

Source: Dahlman (2010)

\section{International Technology Diffusion and Technological Upgrading in Developing Countries}

As discussed earlier, since innovation is costly, risky, and path-dependent, poor countries may have a rationale to rely on foreign technology acquisition for technological development. Foreign sources of technology account for a large part of productivity growth in most countries. In fact, most innovation activities are largely concentrated in a few developed countries: the United States, Japan, and a number of European countries. 
International technology diffusion is therefore an important condition for economic growth. If foreign technologies are easy to diffuse and adopt, a technologically backward country can catch up rapidly, even leapfrog through the acquisition and more rapid deployment of the most advanced technologies (Soete, 1985; Romer, 1994; Grossman and Helpman, 1994; Eaton and Kortum, 1995).

Technology is non-rival; the marginal costs for additional use are negligible. Although frontier technology created through innovation enjoys rents, the public good nature of knowledge suggests that it can generate positive externalities (or spillovers) to others who are also exposed to this knowledge in various ways. However, although some of the technologies can be codified, a large amount of technological knowledge is tacit. Therefore, knowledge spillovers are geographically bounded (Jaffe, Trajtenberg, and Henderson, 1993) because proximity is required to transfer tacit knowledge.

Technology can be diffused between firms and across regions and countries through various transmission mechanisms (Pietrobelli, 1996), including: (i) movement of goods through international trade; (ii) movement of capital through inward and outward foreign direct investment (FDI and OFDI); (iii) movement of people through migration, travel, and foreign education of students and workers; (iv) international research collaboration; (v) diffusion of disembodied knowledge through media and internet; and (vi) integration into global value chains to benefit from the foreign technology transferred within the supply chain. Some knowledge is transferred intentionally from the knowledge owner to the recipient - and this may spur a learning process - but a large proportion of knowledge spillover takes place as unintended leakage. In recent years the mode of innovation is becoming more and more open and is making good use of external resources. International knowledge diffusion can therefore benefit firms at every stage of the innovation process. The growing technological diversification of companies makes successful integration of new external knowledge into the innovation process increasingly important. Such successful integration fosters further innovation. The factors that also explain the accelerating trend of using external sources of knowledge include, among other things, technological convergence, declining costs to acquire external R\&D inputs, and shortening product cycle times (Narula, 2003).

\section{Foreign Direct Investment and Technology Transfer}

Foreign direct investment as a bundle of technological and managerial knowledge, and financial capital has been regarded as a major vehicle for the transfer of advanced foreign technology to developing countries for a long time (Dunning, 1994; Lall, 2003). Multinational enterprises (MNEs) are regarded as the major driver of R\&D in the world. They are also likely to offer training to their employees, though unevenly depending on the case or industry. MNEs are also found to have internal incentives to transfer technology across borders to share technology between parent companies and subsidiaries (Markusen, 
2002). Therefore, it is expected that in the medium to long term, local firms will benefit from MNE spillovers and linkages. The competition effect of FDI is also expected to push inefficient firms out of the market and force other local firms to innovate to be competitive. Technology transfer may take place within the foreign-investing firm through imported machinery and equipment and through labour training. Horizontal technology spillovers may occur from foreign investing firms to other firms in the same industry and/or the same region through demonstration effects and the movement of trained labour from foreign to local firms (Caves, 1974; Fosfuri, Motta, and Ronde, 2001). There may also be vertical technology spillovers taking place between foreign and local suppliers and customers within the value chain through forward and backward linkages (Javorcik, 2004; Pietrobelli and Rabellotti, 2007; Pietrobelli and Saliola, 2008).

Some empirical research shows that technology transferred through FDI has positive effects on developing countries (Kokko, Tansini, and Zejan, 1996; Eden et al., 1997; Buckley, Clegg, and Wang, 2002). However, some of these studies suffer from limitations: they are carried out at the industry level and are likely to be affected by the endogeneity between industry productivity and industry level FDI intensity, and they fail to control for firm-level heterogeneity. An exception is the paper by Javorcik (2004), who investigated the vertical spillovers from FDI through the supply chain using firm-level panel data from Lithuania and found significant positive spillover effects from backward linkages.

Despite the possible benefits of technology transfer and FDI spillover, there may also be significant negative effects on technological upgrading in domestic firms for a variety of reasons. Foreign direct investment may negatively affect the competitiveness of domestic firms and potentially crowd them out of the market (Aitken and Harrison, 1999; $\mathrm{Hu}$ and Jefferson, 2002). Also, strong competition from foreign subsidiaries may reduce R\&D efforts by local firms (OECD, 2002). Moreover, foreign subsidiaries may remain as enclaves in a developing country with a lack of effective linkages to the local economy.

Many developing countries have established export processing zones to attract FDI. Research found that foreign firms located in these zones were mostly engaged in process trade based on cheap unskilled or semi-skilled labour available in the host country and did not generate significant linkages with the local economy (Johansson, 1994). Fu (2004) found that processing trade-oriented FDI in coastal regions of China generated limited linkages and weak spillovers across regions, which exacerbated the existing regional inequalities in China. Using a large firm-level panel data set from China, $\mathrm{Fu}$ and Gong (forthcoming) found depressive effects of foreign $R \& D$ labs on local firms in China. This is likely due to the strong competition for talent, resources, and markets between foreign and indigenous firms, and to the limited linkages between foreign and local firms. Most of the foreign R\&D labs indicated that they had no intention of collaborating with local firms, universities, or research 
institutions because of concerns about protecting intellectual property rights (IPR) (Zhou, 2006).

\section{FDI Is Not an Unalloyed Blessing}

Foreign direct investment is not an unalloyed blessing for technology transfer in developing countries. For an effective technology transfer process, many necessary pre-conditions must be met. First, trade policies. It is argued that openness facilitates linkages, directs resources to the "right" sectors, and creates a competitive and dynamic environment (Balasubramanyam, Salisu, and Sapsford, 1996). Heavy restrictions on foreign investors and import substitution policies do not provide incentives to foreign affiliates for technology transfer (Aitken and Harrison, 1999). Second, legal and regulatory policies, especially those related to IPR, are important. Foreign firms will not bring core technology into their subsidiaries in developing countries with weak IPR protection. They also have little incentive to invest in R\&D and innovate in an environment with weak IPR protection. Third, there need to be sufficient linkages between foreign and local firms to make effective technology transfer possible. In the past, in China joint venture has often been a condition of FDI inflows. China and Brazil have both negotiated export and local content requirements for FDI in certain industries, such as the automobile industry, to create linkages between foreign and local firms. They have also imposed training requirements on FDI in some cases (e.g., Motorola in China). Fourth, different characteristics of FDI benefit technology transfer to a different extent. For example, we expect that investments made by $R \& D$-intensive multinational enterprises from $R \& D$ active countries will - all else being equal - transfer more technology. Technological gaps between foreign and local firms also matter. The relationship between the strength of spillovers and the technology gap follows an inverted-U shape. Spillovers are found to be present when the technology gaps are moderate and when they are much larger (Kokko, Tansini, and Zejan, 1996; Meyer, 2004). Finally, the most necessary condition for effective technology transfer is sufficient absorptive capacity, which we discuss below.

$\mathrm{Fu}$ and Gong (forthcoming) contribute to this debate in a new and original fashion. They explore the sources and drivers of technology upgrading in China's recent wave of science and technology development using a manufacturing firm-level panel data-set for 2001-2005. They decompose total factor productivity growth into technical change and efficiency improvement and examine the drivers of these changes. Their results suggest that FDI has served as a vehicle transferring advanced foreign technology from global reservoirs of knowledge. This improves static technological capabilities through imported machines and equipment. However, R\&D activities of foreign firms appear to exert a significant negative effect on technical change for local firms. Instead, it is collective indigenous innovation that contributes to the dynamic technological capabilities of local firms and pushes forward the technological frontier. 
Firm-level evidence from India further supports this hypothesis. Using unbalanced panel data from 1,843 Indian manufacturing firms operating during the period 1994-2005, Sasidharan and Kathuria (forthcoming) examine the relationship between FDI and domestic firms' R\&D in the post-liberalisation regime. In most regression specifications, they find that the foreign equity participation acts as a disincentive for investment in R\&D. Foreign presence has a positive effect on the R\&D intensity of only new domestic firms, which were incorporated after 1985, during the newly liberalised regime.

Technology spillovers from foreign direct investment may also take place along the spatial/regional dimension. Although knowledge is a non-rival public production asset, which can generate positive externalities or spillovers to others (Nelson, 1959; Griliches, 1979), knowledge spillovers are geographically localised (Jaffe, Trajtenberg, and Henderson, 1993; Audretsch and Feldman, 1996; Audretsch, 1998), and there may be geographic boundaries to information flow or knowledge spillover among the firms in an industry (Marshall, 1920; Krugman, 1991). Social bonds that foster trust and frequent face-to-face contacts may facilitate knowledge and information flow among agents located within the same area (Breschi and Lissoni, 2001). This spatially bound knowledge spillover allows companies operating nearby important knowledge sources to introduce innovations at a faster rate than rival firms located elsewhere.

Using product innovation information for nearly 40,000 Chinese firms in high technology industries over the period 2000-2005, Chen, Li, and Shapiro (2008) investigate the impact of FDI on the product innovation activity of Chinese firms. They find that in locations with a strong clustering of innovative foreign firms, local firms benefit from knowledge spillover and are themselves more likely to introduce product innovations. However, this does not occur in locations where foreign concentration is measured not by innovations but by employment or capital. After controlling for firm- and location-level effects, no general evidence of industry-level spillovers from FDI in the high-technology industries emerges from their analysis. This is consistent with the findings of $\mathrm{Fu}$ and Gong (forthcoming) and Sasidharan and Kathuria (forthcoming). Only the clustering of innovation activities by foreign firms has a knowledge spillover impact on local firms.

\section{Imports and Technology Transfer}

Importing machinery and equipment is another important channel for foreign technology acquisition. Cross-country studies on bilateral import data suggest imports are an important channel for countries to acquire advanced technology and enhance competitiveness (Coe and Helpman, 1995; Fagerberg, 1994; Freeman and Soete, 1997). Note, however, that the technology is embedded in the machinery and equipment. Products produced using these imported machines are probably of higher quality, but this does not mean that developing 
countries necessarily master the technology of designing and producing those advanced machines. Substantial technological learning and reverse engineering are required to grasp the technologies embedded in the imported machinery.

Li (forthcoming) empirically investigates the effect of three types of investment in acquiring technological knowledge (in-house R\&D, importing foreign technology, and purchasing domestic technology) on the innovation output of Chinese domestic firms in hightech industries based on a data set of the National Bureau of Statistics of China (NBSC), China Statistics Yearbook on High Technology Industry, constructed from a panel of 21 four-digit high-tech sectors over the period 1995-2004.

The results show that investing in foreign technology alone does not enhance innovation in domestic firms, unless it is coupled with an industry's own in-house R\&D effort. On the contrary, domestic technology purchases alone are found to contribute to innovation, suggesting that domestic firms can absorb indigenous technology much more easily.

\section{Internationalisation of $R \& D$ and Technology Transfer}

Internationalisation of $R \& D$ activities by multinational enterprises has been a major trend in recent years (UNCTAD, 2006). Many developing and developed countries introduced various selective policies to attract R\&D-related FDI, with the hope that such investments would contribute to building technological capabilities in the host country (Lall, 1992). The evidence on these effects is not clear-cut yet, but Franco, Ray, and Ray (forthcoming) provide original evidence from a comparative study of the innovation practices of multinational affiliates in Brazil and India. Their paper seeks to identify the innovation practices of multinational enterprises in these emerging economies by analysing their technological asset-seeking patterns. Although both countries have similarities in location advantages (large internal markets and abundance of natural resources), multinational affiliates appear to follow significant differences within and across countries in terms of their innovation-oriented strategies. While MNEs in Brazil tend to stand-alone, focusing on one specific kind of technological asset-seeking strategy (licensing, physical capital, or skilled human resources), MNEs in India have adopted a more integrated approach, using complementary innovation practices and combining different kinds of local and foreign knowledge to leverage innovative capabilities. The results suggest that MNEs have different levels of involvement with local productive and innovation systems in Brazil and India. Such heterogeneity in technological assets-seeking behaviour by MNEs combined with different country competencies in attracting knowledge-intensive foreign investments has created different opportunities for these countries to transfer technology and enter global value chains (GVCs). 
In China, innovation practices of MNEs have mostly been stand-alone in the three decades since the reforms. Foreign R\&D centres are reported to have limited interest in sharing knowledge with domestic firms and R\&D labs (Chang et al., 2006; Zhou, 2006). This may be explained by the strict intellectual property rights protection of these high-end MNEs against the indigenous firms. Consistently, Fu and Gong (forthcoming) found that R\&D activities of foreign investment firms at the industry level exert a negative spillover effect on technical change of indigenous firms. Foreign R\&D activities may well intensify competition for the limited domestic talent pool (Chang et al., 2006) and crowd out indigenous firms from local labour, resources, and product markets.

\section{Integration Into Global Value Chain and Technology Transfer}

International knowledge and innovation exchange and collaboration, through for example inter-firm and intra-firm networks and GVCs, has a significant impact on the innovation and technology upgrading of those firms that successfully integrate into the GVC. In developing countries exploiting this potential source of knowledge and learning is especially important given that new frontier innovation is rarely created and the bulk of knowledge and technology needs to be imported. For firms in developing countries, integration into GVCs does not only represent a new market for their products, but it also plays a growing and crucial role in accessing knowledge and enhancing learning and innovation. However, the literature has not yet clearly settled how innovation systems and GVCs interact, and how this interaction is likely to affect enterprise learning.

Pietrobelli and Rabellotti (forthcoming) argue that the different characteristics of the value chains have an impact on the mechanisms of learning in the chain. The learning mechanisms can be very different in the various forms of governance the chain may have: they can be the result of pressure to accomplish international standards or they can be facilitated by direct involvement of the chain leaders when the competence of suppliers is low and the risk of unsatisfactory compliance is very high. When the competencies among actors in the chain are complementary, the learning mechanism is mutual and based on intense face-to-face interactions. Further, as innovation systems open up to foreign knowledge, the relationship between GVCs and such systems turns non-linear and endogenous, with each mutually affecting the other. The authors expect that a well-structured and efficient innovation system may help to reduce the complexity of transactions, and therefore make transactions based on arms' length or on relational forms of GVC governance possible. In other words, the risk of falling into a captive relationship, or even of being acquired by a leader, diminishes with a stronger innovation system. The system of organisations in charge of Metrology, Standards, Testing, and Quality (MSTQ) plays a central role in this interaction, and may affect the convenience of different forms of governance for learning and innovation by firms in developing countries. 


\section{Indigenous Innovations, Appropriate Technology, and Catching-up}

Despite the possible benefits of international technology transfer and the prospect of income convergence among countries brought about by this technology diffusion, empirical evidence on the gains from international knowledge spillover is mixed. ${ }^{6}$ Cross-country studies observed increasing income inequalities between rich and poor countries and the marginalisation of the poorest African countries. One of the explanations of these income divergences is that foreign technology may be inappropriate for the local socio-economic and technical conditions since technological change is a localised learning-by-doing process (Atkinson and Stiglitz, 1969). All this points to the importance of indigenous innovation efforts for technology upgrading, and catching up in particular.

There are different methods and technologies for production, and different technologies are specific to particular combinations of inputs (Basu and Weil, 1998). For a particular country, appropriate technology is "a technology tailored to fit the psychosocial and biophysical context prevailing in a particular location and period" (Willoughby, 1990: 43; on this see also Stewart, 1983). Foreign technology may not fit the specific socioeconomic and technical context prevailing in the country receiving the technology. Moreover, because of the innovator's incentive to maximise returns on their innovation, technical change will be biased to make optimal use of the conditions and factor supplies in the country where the technology is developed (Acemoglu, 2002). Many developing countries use technologies developed in the North, but the factor endowments in the South are significantly different. Therefore, these advanced technologies, no matter whether imported or transferred through FDI, will be inappropriate to the conditions in the South, and hence less productive (Acemoglu and Zilibotti, 1999; Acemoglu, 2002). The direction of technical change and therefore the inappropriateness of the foreign technology used in the South provide a powerful explanation of the increasing income gap across countries. This issue is especially important for the middle-income countries trying to catch up. Although imported technology may contribute to economic growth, the South using inappropriate technology will grow at a lower rate than the North, and the income gap will persist or even rise.

$\mathrm{Fu}$ and Gong (forthcoming) extend the existing literature to the industry level and argue that, in a country that has abundant endowments of unskilled and semi-skilled labour, foreign technology may be less appropriate for the labour-intensive low-technology sector than indigenous technology. The appropriateness of foreign technology may increase as the

\footnotetext{
${ }^{6}$ Görg and Strobl (2001), Blomström and Kokko (1998), and Meyer (2004) are excellent surveys of the literature on spillovers from FDI.
} 
technology-intensity of sectors rises. Since developing countries possess abundant unskilled and semi-skilled labour, indigenous technology will be biased toward those skill levels. In other words, technologies created in labour-abundant countries may augment unskilled labour. In low-technology industries that use unskilled labour intensively, labour-augmenting indigenous technology will be more efficient than foreign technology. In contrast, foreign technology from industrial countries will augment skilled labour, and it will be more efficient than indigenous technology in the technology-intensive sector that uses skilled labour intensively.

Moreover, middle-income countries have accumulated a pool of knowledge and skills, and their factor endowments have become different from those of the least developing countries and of the industrialised countries. Therefore, the large middle-income economies are more likely to generate "intermediate" innovations with medium-level technology intensity than smaller economies with the same degree of capital scarcity (Findlay, 1978). These middle-income countries can reap the gains from investment in such technologies by selling patents, obtaining royalty payments, or investing in smaller and less advanced developing countries (Perez and Soete, 1988). Given the disparities in financial and human capital across different regional or economic social groups in these large middle-income countries, Fu and Gong (forthcoming) expect that such intermediate technology will be generated by the relative skill and capital-rich group of firms in these economies. Using empirical evidence from a recent Chinese manufacturing firm-level panel data set for 20012005, they show that local firms, especially private and shareholding companies, dominate the technological frontier in the low- and medium-technology industries. Indigenous innovation and its diffusion are the driving forces of the dynamic technological capabilities building in the indigenous sector. Instead, foreign firms dominate the high-technology industry. Their study suggests a "two-leg forward" strategy for developing countries (Rifkin, $1975)^{7}$

\section{Foreign Technology Transfer and Indigenous Innovation: Complements or Substitutes}

What is the relationship between foreign technology transfer and indigenous innovation? Should a developing country rely solely on foreign technology because innovation is costly, risky, and path-dependent, or completely depend on indigenous innovation since foreign technologies do not fit the local socio-economic and technical context and they will never be able to create new advanced technology? Or should they pursue both strategies with different

\footnotetext{
${ }^{7}$ This conclusion is also supported by other studies that show how firms have little difficulty in absorbing technological knowledge purchased domestically (Li, forthcoming).
} 
emphasis but at different development stages and in different industries, as suggested by Aghion and Howitt (2005)?

As discussed earlier, several conditions need to be met for technology transfer to be effective in developing countries. A crucial condition is the level of absorptive capacity. Technology transfer can be partial because of the costs and variations in capacity to adopt new technology. The benefits from international knowledge transfer are hence subject to the existence of adequate absorptive capacity of the local firms and organisations - that is the ability of an organisation to identify, assimilate, and exploit knowledge from its surrounding environment (Cohen and Levinthal, 1989; Girma, 2005). In turn, absorptive capacity depends on the human capital and R\&D expenditures of the receiving country or organisation. Crosscountry studies find that there is a minimum necessary threshold level of human capital (Eaton and Kortum, 1995; Xu, 2000), and smaller firm-size or a lower share of skilled workers may hinder absorptive capacity (Girma, 2005). Another important component of absorptive capacity is the R\&D activities carried out by local firms, which play the dual role of creating knowledge and promoting learning and absorptive capacity (Aghion and Howitt, 1998; Griffith, Redding, and Reenen, 2004). R\&D activities in local universities and research institutions also importantly contribute to a region's (or a country's) absorptive capacity. In sum, there are multiple avenues whereby indigenous $R \& D$ is necessary to obtain greater gains from foreign technology transfer. $\mathrm{Li}$ (forthcoming) and $\mathrm{Fu}$ (2008) both support this hypothesis based on experiences from China. Foreign technology will generate technological change and upgrading for local firms only insofar as sufficient indigenous R\&D activities and human capital are present.

On the other hand, would openness to FDI - and the ensuing foreign technology transfer - crowd out local R\&D? Sasidharan and Kathuria (forthcoming) address this major research question and examine the relationship between FDI and the R\&D by domestic firms in the post-liberalisation regime in India. They find that foreign equity participation acts as a disincentive for investment in R\&D in most cases except new local firms. This is consistent with Lokshin, Gils, and Bauer (2008) who suggest that in Europe, internal and external R\&D are complementary, and that institutional and governance structures play a significant role in this process. Thus, it may well be that in India the firms that evolved during the liberalisation regime and have modern institutional and governance structures are more likely to effectively integrate the benefits of domestic and foreign innovation efforts. 


\section{Conclusions}

This article explores in depth the role of indigenous and foreign innovation efforts in technological change and catching up in emerging economies on the basis of a series of new empirical studies. ${ }^{8}$ It also looks at the interaction between indigenous and foreign innovation. The evidence suggests that, despite the potential offered by globalisation and a liberal trade regime, the benefits of international technology diffusion can only be delivered with parallel indigenous innovation efforts ( $\mathrm{Li}$, forthcoming; $\mathrm{Fu}, 2008$ ) and the presence of modern institutional and governance structures and a conducive innovation system (Sasidharan and Kathuria, forthcoming; Pietrobelli and Rabellotti, forthcoming). In this sense, indigenous and foreign innovation efforts are complementary. Without proactive indigenous innovation efforts, foreign technology remains only static technology embedded in imported machines that will never turn into real indigenous technological capability. This conclusion is compounded by the expected inappropriateness of Northern technology for countries in the developing South, which calls for greater efforts to develop indigenous innovation crucial for technological change and catch up, especially in middle-income countries (Fu and Gong, forthcoming). Thus, indigenous and foreign innovation efforts need to be complementary for several reasons that are self-reinforcing.

First, technology diffusion and adoption is not costless and unconditional. The speed of diffusion and adoption, and thereby of building technological capabilities, depends on a firms' absorptive capacity and its complementary assets. Empirical evidence from emerging economies illustrates this ( $\mathrm{Fu}, 2008$; Li, forthcoming). Second, only if local innovation capacity is available will multinational enterprises adopt a more integrated innovation practice, with greater linkages to the local economy and thereby greater opportunities for knowledge transfer (Franco, Ray, and Ray, forthcoming). Third, greater use of external knowledge is accompanied by a parallel decrease in internal R\&D departments (Chesbrough, 2003; Howells, James, and Malik, 2004), especially in research-intensive industries (Bönte, 2003). Recent studies could not support the hypothesis of positive spillover effects from R\&D activities of MNEs on the innovation and technical change of local firms because of significant disincentives for local firms and crowding out of local R\&D (Fu and Gong, forthcoming). Fourth, the inappropriateness of foreign technology in these emerging markets helps explain the poor statistical significance and even the negative effects of FDI spillover. As Lall (2003) suggests, the higher a country moves up the industrial ladder, the more important local capabilities and innovation are. While FDI can facilitate the development of basic operational capabilities, it may be a less efficient means of deepening capabilities. Collective indigenous innovation efforts are found to be a major driver of indigenous technical change (Fu and Gong, forthcoming).

\footnotetext{
${ }^{8}$ Forthcoming in a Special Section of World Development edited by the authors of the present paper.
} 
Admittedly, developing countries face a dilemma of resource constraints to meet the high investment costs and high-risk challenges of innovation (Erdilek, 1984; Hoekman, Maskus and Saggi, 2004). The North-South technology gap in several industries remains remarkably persistent. Experiences from the emerging economies suggest that, to maximise the benefits of innovation and accelerate catch up, the explicit and well-focused encouragement of indigenous innovation and acquisitions of foreign knowledge must work in parallel (Fu and Gong, forthcoming). Neither autonomous innovations nor FDI-reliant strategies are successful independently (Lall, 2003; Pietrobelli, 2000). Relying solely on one would not be optimal for technological capability development and catching up. The Chinese model (and to a lesser degree also the Indian and Brazilian models) of walking on two legs proposes a strategy to maximise the benefits for developing countries (Rifkin, 1975). How to select and shape the best combinations at different stages of development and for different countries and industries is a question of utmost relevance for future research. Fu and Gong (forthcoming) suggest that there are numerous and multi-tier choices of technology rather than the simple bi-dimensional North-South divide. Technologies developed in labour-rich emerging economies will be more appropriate for the factor endowments mix in other populous developing countries; technologies created in land/resource-rich emerging economies will be more appropriate for other land/resource abundant countries. Technologies for similar emerging economies will also be easier to diffuse and local firms will absorb them more effectively. On this basis, South-South trade and FDI will represent effective vehicles for the diffusion of these technologies, and policies should follow suit consistently. In sum, the encouragement of indigenous $R \& D$ and innovation activities remains an indispensable centrepiece of an innovation strategy targeting the assimilation and adaptation of foreign technology and the acceleration of technological learning and of building capabilities. 


\section{References}

Acemoglu, D. 2002. Directed Technical Change. Review of Economic Studies 69: 781-810.

Acemoglu, D. and F. Zilibotti. 1999. Information Accumulation in Development. Journal of Economic Growth, Springer 4(1): 5-38.

Aghion, P. and P. Howitt. 1998. Endogenous Growth Theory. Cambridge, Massachusetts: MIT Press.

Aghion, P. and P. Howitt. 2005. Growth with Quality-Improving Innovations: An Integrated Framework. In Handbook of Economic Growth, eds. P. Aghion and S.N. Durlauf. Vol. 1A, Chapter 2, pp. 67-110. Amsterdam: Elsevier.

Aitken, B.J. and A.E. Harrison. 1999. Do Domestic Firms Benefit from Direct Foreign Investment? Evidence from Venezuela. American Economic Review 89(3): 605-18.

Atkinson A.B. and J.E. Stiglitz. 1969. A New View of Technological Change. Economic Journal 79: 573-78.

Audretsch, D. 1998. Agglomeration and the Location of Innovative Activity. CEPR Discussion Papers, No. 1974.

Audretsch, D. and M. Feldman. 1996. R\&D Spillovers and the Geography of Innovation and Production. American Economics Review 86(3): 630-40.

Balasubramanyam, V.N., M. Salisu, and D. Sapsford. 1996. Foreign Direct Investment and Growth in EP and IS countries. Economic Journal 106: 92-105.

Basu, S. and D.N. Weil. 1998. Appropriate Technology and Growth. Quarterly Journal of Economics 113: 1025-54.

Blomström, Magnus and Ari Kokko. 1998. Multinational Corporations and Spillovers. Journal of Economic Surveys 12: 247-77.

Bönte, W. 2003. Innovation and Employment Growth in Industrial Clusters: Evidence from Aeronautical Firms in Germany. ERSA conference papers, ersa03 p.284, European Regional Science Association.

Breschi, S. and F. Lissoni. 2001. Knowledge Spillovers and Local Innovation Systems: A Critical Survey. Industrial and Corporate Change 10(4): 975-1004.

Buckley, P., J. Clegg, and C. Wang. 2002. The Impact of Inward FDI on the Performance of Chinese Manufacturing Firms. Journal of International Business Studies 38: 447--59.

Caves, R.E. 1974. Multinational Firms, Competition and Productivity in Host-Country Markets. Economica 41(162): 176-93. 
Chang, Y., C. Shih, Y. Luh, and S. Wu. 2006. MNE's Global R\&D Strategy in Developing Countries: A Study of Foreign-Affiliated R\&D Centres in Taiwan. Paper presented at IAMOT 2006, Tsinghua University, Beijing, May 22-26.

Chen, D., J. Li, and D. Shapiro. 2008. FDI Knowledge Spillovers and Product Innovations of Chinese Firms. University of Oxford, SLPTMD Working Paper No. 028.

Chesbrough, H. 2003. The Era of Open Innovation. Sloan Management Review 44(3): 35-41.

Coe, D. and E. Helpman. 1995. International R\&D spillovers. European Economic Review 39: 859-87.

Cohen, W. and D. Levinthal. 1989. Innovation and Learning: Two Faces of R\&D. Economic Journal (99): 569-96.

Dahlman, C. 2010. Innovation Strategies in Brazil, China and India: From Imitation to Deepening Technological Capability in the South. In The Rise of Technological Power in the South, eds. Fu and Soete. London and New York: Palgrave MacMillan.

Dunning, J.H. 1994. Multinational Enterprises and the Globalization of Innovatory Capacity. Research Policy, 23: 67-88.

Eaton, J. and S. Kortum. 1995. Engines of Growth: Domestic and Foreign Sources of Innovation. National Bureau of Economic Research, Inc. Working Paper 5207.

Eden, L., E. Levitas, and R.J. Martinez. 1997. The Production, Transfer and Spillover of Technology: Comparing Large and Small Multinationals as Technology Producers. Small Business Economics 9(1): 53-66.

Erdilek, A. 1984. International Technology Spillovers in the Middle East and North Africa. Management Decision 22(2): 45-9.

Fagerberg, J. 1994. Technology and International Differences in Growth Rate. Journal of Economic Literature 32(3): 1147-1175.

Findlay, R. 1978. Relative Backwardness, Direct Foreign Investment and the Transfer of Technology: A Simple Dynamic Model. Quarterly of Journal of Economics February: 1-16.

Fosfuri, A., M. Motta, and T. Ronde. 2001. Foreign Direct Investment and Spillovers through Workers' Mobility. Journal of International Economics 53(1): 205-22.

Freeman, C. and L. Soete. 1997. The Economics of Industrial Innovation, 3rd ed. London: Pinter.

Freeman, R. 2005. Does Globalization of the Scientific/Engineering Workforce Threaten U.S. Economic Leadership. National Bureau of Economic Research, Inc. Working Paper 11457. 
Fu, X. 2004. Limited Linkages from Growth Engines and Regional Disparities in China. Journal of Comparative Economics 32(1): 148-64.

Fu, X. 2008. Foreign Direct Investment, Absorptive Capacity and Regional Innovation Capabilities: Evidence from China. Oxford Development Studies 36(1): 89-110.

$\mathrm{Fu}, \mathrm{X}$. and Y. Gong. Forthcoming. Indigenous and Foreign Innovation Efforts and Drivers of Technological Upgrading: Evidence from China. World Development, Special Section.

Franco E., S. Ray, and P.K. Ray. Forthcoming. Patterns of Innovation Practices of Multinational-affiliates in Emerging Economies: Evidences from Brazil and India. World Development, Special Section.

Girma, S. 2005. Absorptive Capacity and Productivity Spillovers from FDI: A Threshold Regression Analysis. Oxford Bulletin of Economics and Statistics 67(3): 281-306.

Görg, H. and E. Strobl. 2001. Multinational Companies and Productivity Spillovers: A MetaAnalysis. Economic Journal 111: F723-F739.

Griffith, R., S. Redding and J.V. Reenen. 2004. Mapping the Two Faces of R\&D: Productivity Growth in a Panel of OECD Industries. Review of Economics and Statistics 86(4): 883-95.

Griliches, Z. 1979. Issues in Assessing the Contribution of Research and Development to Productivity Growth. Bell Journal of Economics 10(1): 92-116.

Grossman, G. and E. Helpman. 1994. Technology and Trade. National Bureau of Economic Research, Inc. Working Paper 4926.

Hoekman, B., K.E. Maskus and K. Saggi. 2004. Transfer of Technology to Developing Countries: Unilateral and Multilateral Policy Options. Policy Research Working Papers Series No. 3332. Washington, D.C.: The World Bank.

Howells, J., A. James, and K. Malik. 2004. Sourcing External Technological Knowledge: A Decision Support Framework for Firms. International Journal of Technology Management 27(2/3): 143-55.

Hu A.G.Z. and Jefferson G.H. 2002. FDI Impact and Spillover: Evidence from China's Electronic and Textile Industries. World Economy 38 (4): 1063-1076.

Jaffe, A.B., M. Trajtenberg, and R. Henderson. 1993. Geographic Localization of Knowledge Spillovers as Evidenced by Patent Citations. The Quarterly Journal of Economics 108(3): 577-98. 
Javorcik, B.S. 2004. Does Foreign Direct Investment Increase the Productivity of Domestic Firms? In Search of Spillovers through Backward Linkages. American Economic Review 94(3): 605-27.

Johansson, H. 1994. The Economics of Export Processing Zones Revisited. Development Policy Review 12(4): 387-402.

Kokko, A., R. Tansini, and M. Zejan. 1996. Local Technological Capability and Productivity Spillovers from FDI in the Uruguayan Manufacturing Sector. Journal of Development Studies 32(4): 602-11.

Krugman, P. 1991. Increasing Returns and Economic Geography. Journal of Political Economy 99(3): 483-499.

Lall, S. 1992. Technological Capabilities and Industrialization. World Development 20(2): 165-186.

Lall, S. 2003. Foreign Direct Investment, Technology Development and Competitiveness: Issues and Evidence. In Competitiveness, FDI and Technological Activity in East Asia, eds. S. Lall and S. Urata. Published in association with the World Bank. Cheltenham, UK: Edward Elgar.

Lall, S. and S. Urata. 2003. Introduction and Overview. In Competitiveness, FDI and Technological Activity in East Asia, eds. S. Lall and S. Urata. Published in association with the World Bank. Cheltenham, UK: Edward Elgar.

Lall, S. 2001. Competitiveness, Technology and Skills. Cheltenham: Edward Elgar.

Lall, S. 2005. Rethinking Industrial Strategy: The Role of the State in the Face of Globalization. In Putting Development First. The Importance of Policy Space in the WTO and IFIs, ed. K.P. Gallagher. London and New York: ZED Books, pp.33-68.

Li, X. Forthcoming. Sources of External Technology, Absorptive Capacity and Innovation Capability in Chinese State-Owned High-Tech Enterprises. World Development, Special Section.

Lokshin, B., A. Gils and E. Bauer. 2008. Crafting Firm Competencies to Improve Innovative Performance. United Nations University, Maastricht Economic and social Research and training centre on Innovation and Technology (UNU-MERIT) Working Paper Series 009.

Markusen, J. R. 2002. Multinational Firms and the Theory of International Trade. Cambridge, Massachusetts: MIT Press.

Marshall, A. 1920. Principles of Economics. London: Macmillan and Co., Ltd. 
Meyer, K. E. 2004. Perspectives on Multinational Enterprises in Emerging Economies. Journal of International Business Studies 35: 259-276.

Narula, R. 2003. Globalization and Technology. Interdependence, Innovation Systems and Industrial Policy. Cambridge, U.K.: Polity Press.

Nelson, R.R. 1959. The Simple Economics of Basic Scientific Research. Journal of Political Economy 67: 297-306.

Organization for Economic Cooperation and Development. 2002. Science and Technology Industry Outlook. Paris: OECD.

Perez, C. and L. Soete. 1988. Catching Up in Technology: Entry Barriers and Windows of Opportunity. In Technical Change and Economic Theory, eds. G. Dosi et al. London: Pinter, pp. $458-479$.

Pietrobelli C. 1996. Emerging Forms of Technological Cooperation: The Case for Technology Partnerships - Inner Logic, Examples and Enabling Environment. Science and Technology Issues. Geneva: UNCTAD - United Nations.

Pietrobelli C. 2000. The Role of International Technology Transfer in the Industrialisation of Developing Countries. In Technology Transfer, eds. M. Elena and D. Schroeer. Aldershot, UK; Burlington, USA: Ashgate.

Pietrobelli C. and R. Rabellotti (eds.). 2007. Upgrading to Compete: SMEs, Clusters and Value Chains in Latin America. Cambridge Massachusetts: Harvard University Press.

Pietrobelli C. and R. Rabellotti. Forthcoming. Global Value Chains Meet Innovation Systems: Are There Learning Opportunities for Developing Countries. World Development, Special Section.

Pietrobelli C. and F. Saliola. 2008. Power Relationships along the Value Chain: Multinational Firms, Global Buyers, and Local Suppliers' Performance. Cambridge Journal of Economics 32(6), pp. 947-62.

Rifkin S.B., 1975. The Chinese Model for Science and Technology: Its Relevance for Other Developing Countries. Technological Forecasting and Social Change, Volume 7, Issue 3, 1975, pp.257-71.

Romer, P. 1994. The Origins of Endogenous Growth. Journal of Economic Perspectives, American Economic Association 8(1): 3-22.

Sasidharan S. and V. Kathuria. Forthcoming. Foreign Direct Investment and R\&D: Substitutes or Complements: A Case of Indian Manufacturing after 1991 Reforms. World Development, Special Section. 
Soete, L. 1985. International Diffusion of Technology, Industrial Development and Technological Leapfrogging. World Development 13(3): 409-22.

Stewart, F. 1983. Macro-Policies for Appropriate Technology: An Introductory Classification. International Labour Review 122(3): 279-93.

UNCTAD. 2006. World Investment Report. Geneva: United Nations.

Willoughby, K.W. 1990. Technology Choice: A Critique of The Appropriate Technology Movement. Boulder, Co.: Westview Press,

World Bank. 2007. World Development Report. Washington, D.C.: World Bank.

World Bank. 2010. World Development Indicators. Washington, D.C.: World Bank.

$\mathrm{Xu}$, B. (2000). Multinational Enterprises, Technology Diffusion, and Host Country Productivity Growth. Journal of Development Economics 32: 1258-74.

Zhou, Y. 2006. Features and Impacts of the Internationalisation of R\&D by Transnational Corporations: China's Case. In Globalisation of $R \& D$ and Developing Countries. New York and Geneva: UNCTAD, United Nations. 